\title{
POPYT NA SAMOCHODY OSOBOWE O DUŻEJ POJEMNOŚCI SILNIKA W POLSCE - ANALIZA PRZESTRZENNO-CZASOWA
}

\section{Wstęp}

Artykuł zawiera przestrzenno-czasową analizę popytu na samochody osobowe o dużej pojemności silnika w polskich województwach w latach 20032011. Pod pojęciem dużej pojemności silnika należy rozumieć pojemność większą od $2000 \mathrm{~cm}^{3}$. Uwzględniono wiele czynników kształtujących omawiany popyt, mianowicie:

- możliwość zakupu,

- koszt użytkowania,

- jakość użytkowania,

- bezpieczeństwo użytkowania,

- skłonność do zakupu.

$\mathrm{W}$ analizach pominięto cenę samych aut, ponieważ dla różnych marek cena jest na tyle zróżnicowana, że nie dało się określić uśrednionej wartości tej zmiennej. Taka analiza popytu (nieuwzględniająca ceny danego dobra) jest podejściem raczej rzadko praktykowanym. Natomiast biorąc pod uwagę fakt, że w przedmiocie badania znalazły się samochody osobowe o dużej pojemności silnika, których popyt zależy od wielu czynników losowych (w tym czynnika potocznie nazwanego „szpanem”, przy którym skłonność do zakupu często jest większa niż analiza zawyżonej ceny - tzw. paradoks Veblena') można było przyjąć takie niekonwencjonalne podejście.

Artykuł zawiera również obszernie omówiony aspekt teoretyczny wykorzystania modeli panelowych (zarówno $\mathrm{z}$ dekompozycją wyrazu wolnego o ustalonych efektach grupowych - Fixed Effects Model, jak i dekompozycją składnika losowego - Random Effects Model), uwzględniający umiejętność odpowiedniego doboru modelu w zależności od badanego zjawiska (poprzez stosowanie testów: Chowa, Breuscha-Pagana oraz Hausmana). Właśnie tego typu modele zostały użyte do przestrzenno-czasowej analizy popytu na auta o dużej pojemności silnika w polskich województwach w latach od 2003 do 2011.

*Doktorant, Katedra Ekonometrii Przestrzennej, Wydział Ekonomiczno-Socjologiczny UŁ.

${ }^{1}$ Paradoks ten dotyczy głównie zamożnych klientów, którzy nie chcą nabywać danego dobra po zbyt niskiej cenie, gdyż uważają, że nie jest ono wtedy wystarczająco prestiżowe. Powoduje to sytuacje, w której wraz ze wzrostem ceny danego dobra paradoksalnie rośnie popyt na to dobro. Zob. R.Milewski, E. Kwiatkowski (red.), Podstawy ekonomii, Wyd. Nauk. PWN, Warszawa 2007, s. $48-49$. 


\section{Teoretyczne aspekty zastosowania modeli panelowych}

Modele panelowe są znacznie bardziej złożone niż modele oparte na zwykłych szeregach czasowych i jednocześnie bardziej rozbudowane niż modele przekrojowe ${ }^{2}$, wykazują bowiem powiązania przestrzenno-czasowe badanych obiektów, obszarów lub regionów na przestrzeni badanych okresów czasowych (dni, tygodni, miesięcy, lat itd.). Bazy danych stosowane do analizowania tego typu modeli stanowią rozległe tabele, dlatego też często występuje problem ze zbieraniem tak dużej liczby zmiennych oraz występowaniem braków w danych. Do estymacji jednorównaniowego modelu ekonometrycznego posłużą dane panelowe w postaci:

$$
y_{i t}=\alpha+\mathbf{X}_{i t}^{\prime} \beta+u_{i t}, \text { dla } i=1, \ldots, N, t=1, \ldots, T,
$$

gdzie:

$i$ - obiekt (w przedmiocie badania województwo),

$t$ - czas (podstawową jednostką w przedmiocie badania jest rok),

$\mathbf{X}_{i t}^{\prime}$ - wektor obserwacji na zmiennych objaśniających o K współrzędnych,

$\alpha$ - wyraz wolny (niezmienny w czasie i przestrzeni),

$u_{i t}-$ składnik losowy.

W przypadku, gdy składnik losowy jest rozbijany na dwa komponenty, czyli $u_{i t}=\mu_{i}+v_{i t}$, gdzie $\mu_{i}$ to nieobserwowalny $\mathrm{i}$ nieuwzględniony $\mathrm{w}$ równaniu regresji efekt wynikający jedynie z przynależności do $i$-tej grupy, natomiast $v_{i t}$ jest odwzorowaniem pozostałej części składnika losowego to model taki nosi nazwę modelu podstawowego. Postać macierzową takiego modelu zapisać można jako następujące równanie:

$$
\mathbf{y}=\alpha \mathbf{i}_{N T}+\mathbf{X} \beta+\mathbf{u}=\alpha \mathbf{i}_{N T}+\mathbf{X} \beta+\mathbf{Z}_{\mu} \mu+v=\mathbf{Z} \delta+\mathbf{u},
$$

gdzie:

$\mathbf{y}$ - wektor zmiennych endogenicznych o $N T$ współrzędnych,

$\mathbf{X}$ - macierz zmiennych objaśniających o wymiarach $(N T x K)$,

$\mathbf{i}_{N T}$ - wektor jedynek o $N T$ współrzędnych,

$\mathbf{Z}_{\mu}=\mathbf{I}_{N} \otimes \mathbf{i}_{T}-$ macierz selekcjonująca (składająca się z zer i jedynek), zwana również macierzą zmiennych sztucznych.

${ }^{2}$ Cały podrozdział napisany na podstawie: B. Dańska-Borsiak, Przestrzenno-czasowe modelowanie zmian $w$ działalności produkcyjnej $w$ Polsce, zastosowanie modeli panelowych. t. 1, [w:] B. Suchecki (red.), Dane panelowe $i$ modele wielowymiarowe $w$ badaniach ekonomicznych, Absolwent, Łódź 2000, s. 36-42. 
Ponadto $\mu^{\prime}=\left(\mu_{1}, \ldots, \mu_{N}\right)$ oraz $v^{\prime}=\left(v_{11}, \ldots, v_{1 T}, \ldots, v_{N 1}, \ldots, v_{N T}\right)$. Przyjmując, że $\mu$ to wektor nielosowych parametrów, które będą estymowane, a $v$ to wektor składników losowych o takich samych, niezależnych rozkładach: $v_{i t}: N\left(0, \sigma_{v}^{2}\right)$, $X_{i t}$ są niezależne od $v_{i t}$ dla wszystkich $i, t$ to mowa o modelu z dekompozycją wyrazu wolnego (z ustalonymi efektami grupowymi, ze zmiennymi sztucznymi - Fixed Effects Model - FEM):

$$
\mathbf{y}=\alpha \mathbf{i}_{N T}+\mathbf{X} \beta+\mathbf{Z}_{\mu} \mu+v=\mathbf{Z} \delta+\mathbf{Z}_{\mu} \mu+v
$$

Do oszacowania wektorów $\alpha, \beta$ i $\mu$ posłuży Metoda Najmniejszych Kwadratów (MNK). Jednakże macierz $\mathbf{Z}$ jest wymiaru $N \operatorname{Tx}(K+1)$, macierz $\mathbf{Z}_{\mu}$ jest wymiaru $N T x N$, w związku z czym do zastosowania MNK konieczne jest odwrócenie macierzy stopnia $N+K$, co jest dość kłopotliwe dla dużych $N$. $Z$ tej przyczyny równanie (3) mnoży się stronami przez tzw. operator wewnątrzgrupowy $\mathbf{Q}$. Dzięki temu przekształca się wszystkie zmienne w odchylenia od średniej grupowej oraz eliminuje z modelu wszystkie efekty grupowe stałe w czasie. Do zastosowania MNK w przekształconym w ten sposób równaniu (3) konieczne jest odwrócenie macierzy stopnia $K$, co już nie stwarza większych problemów. Odpowiedni estymator wektora $\beta$ to estymator MNK ze zmiennymi sztucznymi, lub estymator wewnątrzgrupowego:

$$
\beta_{w}^{\sim}=\left(\mathbf{X}^{\prime} \mathbf{Q X}\right)^{-1} \mathbf{X}^{\prime} \mathbf{Q} \mathbf{y}
$$

Znając oceny równania (4) można, na podstawie odpowiednich średnich obliczyć oceny parametrów $\alpha$ i $\mu_{i}$. Parametry $\mu_{i}$ wiążą się z przekształceniem wyrazu wolnego (odchylenia grupowe od wspólnej średniej $\alpha$ ). Należy zaznaczyć, że w sytuacji, gdy $N$ jest bardzo duże (próba gromadzi informacje o bardzo dużej liczbie obiektów) wykorzystywanie wyżej omówionych metod jest problematyczne, gdyż pojawia się konieczność wprowadzenia do równania regresji dodatkowych $(N-1)$ zmiennych sztucznych, co powoduje znaczną utratę stopni swobody. Ponadto, jeżeli jednocześnie $T$ nie wzrasta, to estymatory $\alpha^{\sim}$ i $\mu_{i}^{\sim}$ tracą zgodność. Problemów tych można uniknąć jeśli założy się, że $\mu_{i}$ jest zmienną losową, tzn., że składnikiem losowym modelu (2) jest $\mathbf{u}=\mathbf{Z}_{\mu} \mu+v$. Model taki nosi nazwęRandom Effects Model (REM), czyli model z dekompozycją składnika losowego. W takich modelach przyjmuje się, że $v$ i $\mu$ są niezależne, $v_{i t}: N\left(0, \sigma_{v}^{2}\right), \mu_{i t}: N\left(0, \sigma_{\mu}^{2}\right), X_{i t}$ są niezależne od $v_{i t}$ i $\mu_{i t}$ 
dla wszystkich $i, t$. Macierz $\boldsymbol{\Omega}$ wariancji - kowariancji składnika losowego $\mathbf{u}=\mathbf{Z}_{\mu} \mu+v$ ma postać:

$$
\boldsymbol{\Omega}=E\left(\mathbf{u} \mathbf{u}^{\prime}\right)=\sigma_{\mu}^{2}\left(\mathbf{I}_{N} \otimes \mathbf{J}_{T}\right)+\sigma_{v}^{2}\left(\mathbf{I}_{N} \otimes \mathbf{I}_{T}\right) .
$$

Da się zauważyć występowanie korelacji w czasie pomiędzy składnikami losowymi dotyczącymi tych samych obiektów i jej brak pomiędzy składnikami losowymi różnych obiektów w różnych okresach. Do estymacji parametrów należy zatem użyć uogólnionej metody najmniejszych kwadratów (UMNK). Niesie to ze sobą jednak konieczność odwrócenia macierzy $\boldsymbol{\Omega}$ stopnia $N T$. Dlatego też wyjściowe równanie (2) przekształca się dwukrotnie: po pierwsze przy pomocy operatora wewnątrzgrupowego $\mathbf{Q}$ i po drugie za pomocą operatora międzygrupowego $\mathbf{P}$ (pomnożenie dowolnej macierzy przez ten operator przekształca ją w macierz średnich grupowych). Następnie używając na tych dwóch równaniach regresji wewnątrzgrupowej i międzygrupowej jako układ $2 N T$ równań, estymuje się jego parametry UMNK, co jest równoważne zastosowaniu tej metody do estymacji równania (2). Obliczony w ten sposób estymator wektora $\beta$ przyjmuje postać:

$$
\beta_{U M N K}^{\wedge}=\left[W_{X X}+\varnothing^{2} B_{X X}\right]^{-1}\left[W_{X y}+\varnothing^{2} B_{X y}\right],
$$

gdzie:

$$
\begin{aligned}
& W_{X X}=\mathbf{X}^{\prime} \mathbf{Q X}, \\
& B_{X X}=\mathbf{X}^{\prime}\left(\mathbf{P}-\mathbf{J}_{N T}^{-}\right) \mathbf{X}, \\
& \varnothing^{2}=\sigma_{v}^{2} / \sigma_{1}^{2}, \\
& \sigma_{1}^{2}=T \sigma_{\mu}^{2}+\sigma_{v}^{2}, \\
& \mathbf{J}_{N T}^{-}=(N T)^{-1} \mathbf{J}_{N T}, \\
& \mathbf{J}_{N T} \text { to macierz jedynkowa stopnia } N T .
\end{aligned}
$$

Estymator ten jest ważoną średnią estymatora wewnątrzgrupowego $\beta_{w}^{\sim}$ danego wzorem (4) i estymatora międzygrupowego $\beta_{b}^{\sim}=B_{X X}^{-1} B_{X y}$.

\section{Weryfikacja statystyczna modeli FEM i REM}

Test Chowa (F) stosuje się do sprawdzenia czy wprowadzenie dekompozycji wyrazu wolnego dla poszczególnych obiektów lub obszarów było istotne $\mathrm{w}$ badanym zjawisku. Hipoteza zerowa mówi o tym, że wyrazy dla grup nie różnią się w sposób istotny i przyjmuje postać: 


$$
H_{0}: \mu_{1}=\mu_{2}=\ldots=\mu_{N-1}=0 \text {. }
$$

Statystyka służąca do weryfikacji tej hipotezy przyjmuje postać:

$$
F_{0}=\frac{(R R S S-U R S S) /(N-1)}{U R S S /(N T-N-K)},
$$

gdzie:

RRSS - suma kwadratów reszt MNK dla wszystkich obserwacji,

URSS - suma kwadratów reszt uzyskanych przy zastosowaniu estymatora wewnątrzgrupowego.

Statystyka testu Chowa ma rozkład $F$ o $N-1$ i $N(T-1)-K$ stopniach swobody. Jeżeli wartość $F_{0}$ jest wyższa od wartości krytycznej to $H_{0}$ należy odrzucić na korzyść hipotezy alternatywnej mówiącej o tym, że wprowadzenie dekompozycji wyrazu wolnego było istotne.

Test Breuscha-Pagana (inaczej zwany testem mnożnika Lagrange'a), sprawdza, czy model z dekompozycją składnika losowego jest statystycznie lepszy niż model bez efektów grupowych. Hipoteza zerowa ma postać:

$$
H_{0}: \sigma_{\mu_{i}}^{2}=0
$$

i mówi ona o tym, że dekompozycja składnika losowego była nieistotna. Natomiast hipoteza alternatywna ma postać:

$$
H_{1}: \sigma_{\mu_{i}}^{2} \neq 0
$$

i mówi o tym, że wprowadzenie składnika losowego było istotne i uzasadnione. Do weryfikacji hipotezy zerowej wykorzystywana jest statystyka:

$$
L M=\frac{N T}{2(T-1)}\left[\frac{\sum_{i}\left(\sum_{t} e_{i t}\right)^{2}}{\sum_{i} \sum_{t} e_{i t}^{2}}-1\right]^{2},
$$

gdzie $e_{i t}$ to reszty modelu nie wyróżniającego efektów grupowych.

Statystyka testu LM ma rozkład $\chi^{2} \mathrm{z}$ jednym stopniem swobody. Jeżeli wartość statystyki $L M$ jest wyższa od wartości krytycznej to należy odrzucić 
$H_{0}$ na korzyść hipotezy alternatywnej mówiącej o tym, że efekty grupowe są istotne oraz wprowadzenie dekompozycji wyrazu wolnego było uzasadnione.

Podstawowym założeniem dla modeli panelowych jest brak korelacji między składnikiem losowym $u_{i t}$ i zmiennymi objaśniającymi, tzn. $E\left(u_{i t} \mid \mathbf{X}_{i t}\right)=0$. Założenie to jest istotne, dlatego że $u_{i t}$ zawiera nieobserwowalną składową $\mu_{i}$, która jest niezmienna w czasie, w związku z czym istnieje możliwość, że jest ona skorelowana ze zmiennymi objaśniającymi. Gdy taka korelacja występuje, to estymator $\beta_{U M N K}^{\wedge}$ stosowany do estymacji modeli z dekompozycja składnika losowego jest obciążony i niezgodny. Modyfikacja stosowana przy tworzeniu estymatora wewnątrzgrupowego (modele $\mathrm{z}$ dekompozycją wyrazu wolnego) usuwa efekty grupowe, które są przyczyną korelacji. Dlatego $\beta_{w}^{\wedge}$ jest zgodny i nieobciążony.

Istnieje test, zwany testem Hausmana, którego sens opiera się na założeniu prawdziwości hipotezy zerowej wyrażonej w postaci:

$$
H_{0}: E\left(u_{i t} \mid \mathbf{X}_{i t}\right)=0 \text {. }
$$

Oba estymatory $\beta_{U M N K}^{\wedge}$ i $\beta_{w}^{\sim}$ są zgodne, aczkolwiek maja one inne granice stochastyczne jeśli $H_{0}$ jest nieprawdziwa. Test Hausmana opiera się na różnicy między tymi estymatorami, występującej, jeśli $H_{0}$ jest niesłuszna. Statystyka weryfikująca hipotezę zerową ma rozkład $\chi^{2}$ z $K$ stopniami swobody, gdzie $K$ jest liczbą zmiennych objaśniających i wyrazić ją można jako:

$$
m=q_{1}^{\wedge}\left[\operatorname{var}\left(q_{1}^{\wedge}\right)\right]^{\prime} q_{1}^{\wedge}, \text { gdzie: } \hat{q_{1}^{\wedge}}=\beta_{U M N K}^{\wedge}-\beta_{w}^{\sim} .
$$

\section{Dobór zmiennych}

Celem badania jest analiza popytu na samochody osobowe o dużej pojemności silnika $\mathrm{w}$ polskich województwach w latach 2003-2011 ${ }^{3}$. Biorąc pod uwagę znaczącą różnorodność pomiędzy liczbą mieszkańców i wielkością terytorialną poszczególnych województw zmienne poddano odpowiednim przekształceniom. Za zmienną objaśnianą przyjęto:

- SAM - Samochody osobowe o pojemności silnika ponad $2000 \mathrm{~cm}^{3}$ na ogólną liczbę ludności (szt.).

Ogromne zróżnicowanie cen tego typu aut spowodowało pominięcie tego aspektu $\mathrm{w}$ dalszej analizie. W standardowym podejściu analizy popytu na dane

\footnotetext{
${ }^{3}$ Wszystkie zmienne pochodzą z Banku Danych Lokalnych Głównego Urzędu Statystycznego; www.stat.gov.pl, (dostęp 30.11.2012).
} 
dobro, pierwszą i podstawową zmienną jest właśnie cena tego dobra. Natomiast biorąc pod uwagę przedmiot badania jakim jest popyt na samochody osobowe o dużej pojemności silnika, na który wpływ ma wiele czynników losowych oraz występuje problem w oszacowaniu przeciętnej ceny takiego samochodu zastosowano właśnie takie niekonwencjonalne podejście.

Za pierwszy czynnik przyjęto możliwość zakupu wyrażony przez:

- WYN - przeciętne miesięczne wynagrodzenie brutto (zł).

Oczywiście przyjęto, że im większe przeciętne wynagrodzenia społeczeństwa, tym większy powinien być analizowany popyt. Ponieważ zmienna ta wyrażona jest w złotówkach uwzględniono wskaźnik odzwierciedlający inflację w kolejnych latach analizy.

Za drugi czynnik wpływający na zmienną objaśnianą przyjęto koszt użytkowania samochodów. Przewiduje się, że gdy koszt użytkowania samochodów rośnie to popyt będzie spadał (społeczeństwo chętniej skorzysta z alternatywnych usług transportowych lub tańszych aut w eksploatacji). Ten czynnik wyrażony został poprzez zmienną:

- BEN - przeciętna cena benzyny 95 za 11 z uwzględnieniem wskaźnika cen towarów i usług konsumpcyjnych transportowych (zł).

Trzecim czynnikiem kształtującym omawiany popyt jest jakość użytkowania. Zakłada się, że gdy gęstość dróg o twardej nawierzchni zwiększa się, społeczeństwo chętniej kupi samochody droższe i szybsze, gdyż tylko wtedy może w pełni korzystać z udogodnienia posiadania takiego dobra. Ten czynnik wyrażony jest poprzez zmienną:

- DRO - drogi $(\mathrm{km})$ o twardej nawierzchni ulepszonej na $100 \mathrm{~km}^{2}$.

Kolejnym czynnikiem wpływającym na zmienną objaśnianą jest bezpieczeństwo użytkowania. Zakłada się, że im mniejsze bezpieczeństwo użytkowania tym popyt będzie spadał, gdyż jest to przestroga dla potencjalnych nowych kierowców. Ten czynnik wyrażony jest poprzez zmienną:

- OFI - ofiary śmiertelne na 100 tys. pojazdów (os.).

Ostatnim czynnikiem jaki uwzględniono w modelu jest skłonność do zakupu. Przyjęto, że samochody o dużej pojemności silnika chętniej i częściej nabywają mężczyźni. Dlatego też przyjęto, że im więcej mężczyzn w danym województwie w wieku produkcyjnym tym popyt na auta będzie większy. W przypadku dóbr jakim jest dobry samochód mężczyźni często popełniają typowe błędy konsumenta. Bardziej kierują się systemem zewnętrznych wymogów, niż zdrowym rozsądkiem i własnymi możliwościami finansowymi ${ }^{4}$. Determinanty pozaekonomiczne kształtujące decyzję konsumentów można podzielić na dwie grupy: wewnętrzne (demograficzne: wiek, płeć, wielkość gospodarstwa domowego, społeczno-zawodowe: wykształcenie, aktywność

${ }^{4}$ J. Topolska, Podstępny rynek. Zapiski podejrzliwego konsumenta, bis, Warszawa 2000, s. $244-248$. 
zawodowa, społeczne: grupy odniesienia, liderzy opinii) oraz zewnętrzne (cywilizacyjno-kulturowe, geograficzno-przyrodnicze, organizacja życia społecznego $)^{5}$. Czynnik ten określony jest przez zmienną:

- M - mężczyźni w wieku produkcyjnym (17-64 lata) (os.).

\section{Estymacje i weryfikacje statystyczne modeli}

W modelu panelowym analizującym popyt na samochody o dużej pojemności silnika włączono 16 jednostek danych przekrojowych (polskie województwa) dla szeregu czasowego o długości 9 (kolejne lata analizy od roku 2003 do $2011)^{6}$. Pierwszą estymację przeprowadzono za pomocą metody najmniejszych kwadratów (tabela 1).

Tabela 1. Estymacja panelowa MNK (zmienna zależna SAM)

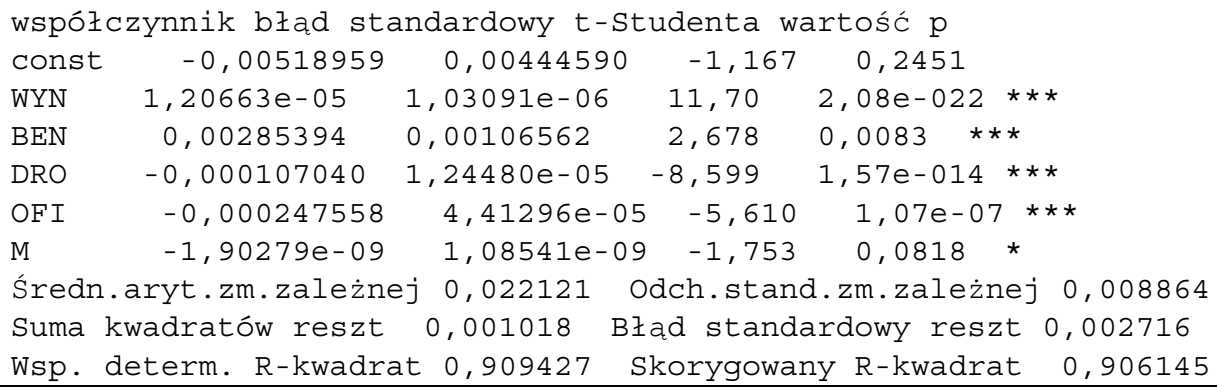

Źródło: opracowanie własne z wykorzystaniem programu Gretl (dotyczy tabel 1-7).

Analizując dane z tabeli 1 można zauważyć, że wszystkie parametry stojące przy zmiennych objaśniających są statystycznie istotne na podstawie statystyki $t$-Studenta. Zmienna $\mathrm{M}$ jest na granicy istotności, natomiast wykazuje niewielki wpływ na zmienną objaśnianą. Problem natomiast pojawia się, gdy analizujemy wyraz wolny. Jest on statystycznie nieistotny, dlatego też można przypuszczać, że w różnych województwach różna jest siła wpływu wyrazu wolnego na badane zjawisko. Biorąc pod uwagę powyższe, dokonano kolejnej estymacji, która uwzględnia dekompozycję wyrazu wolnego dla wszystkich województw (tabela 2).

\footnotetext{
${ }^{5}$ G. Maciejewski, Ryzyko w decyzjach nabywczych konsumentów, Wyd. UE w Katowicach, Katowice 2012, s. 29-31.

${ }^{6}$ Estymacje i weryfikacja statystyczna testów na podstawie: T. Kufel, Ekonometria. Rozwiqzywanie problemów z wykorzystaniem programu GRETL, Wyd. Nauk. PWN, Warszawa 2007, s.164-171.
} 
Tabela 2. Estymacja panelowa FEM (zmienna zależna SAM)

\begin{tabular}{|lccccc}
\hline \multicolumn{2}{l}{ współczynnik bład standardowy t-Studenta } & wartość p \\
const & $-0,0365458$ & 0,00967568 & $-3,777$ & 0,0002 & $* * *$ \\
WYN & $1,81208 e-05$ & $1,06985 e-06$ & 16,94 & $6,06 e-034$ & $* * *$ \\
BEN & 0,000160137 & 0,000712126 & 0,2249 & 0,8225 & \\
DRO & $-0,000381004$ & $5,17290 e-05$ & $-7,365$ & $2,22 e-011$ & $* * *$ \\
OFI & $-0,000124003$ & $3,67988 e-05$ & $-3,370$ & $0,0010 \quad * * *$ \\
M & $5,36356 e-08$ & $1,41536 e-08$ & 3,790 & 0,0002 & $* * *$
\end{tabular}

Średn.aryt.zm.zależnej 0,022121 Odch.stand.zm.zależnej 0,008864 Suma kwadratów reszt 0,000245 Błąd standardowy reszt 0,001410 Wsp. determ. R-kwadrat 0,978222 Skorygowany R-kwadrat 0,974681

Model FEM charakteryzuje się wyższym dopasowaniem niż model podstawowy. Jednak parametr stojący przy jednej ze zmiennych jest statystycznie nieistotny. Dlatego też, aby sprawdzić, który z modeli lepiej opisuje badane zjawisko należy zastosować test Chowa (F).

Tabela 3. Test Chowa (F)

Test na zróżnicowanie wyrazu wolnego w grupach -
Hipoteza zerowa: grupy posiadaja wspólny wyraz wolny
Statystyka testu: $F(15,123)=25,9034$
z wartościa $p=P(F(15,123)>25,9034)=4,92169 e-031$

Na podstawie testu Chowa $(\mathrm{F})=25,9034$ oraz przy empirycznym poziomie prawdopodobieństwa dla tego testu bliskim zeru można odrzucić hipotezę zerową i stwierdzić, że dekompozycja wyrazu wolnego była uzasadniona i potrzebna.

Analizując popyt na samochody o dużej pojemności silnika mamy do czynienia z wieloma czynnikami losowymi. Dlatego też dokonano kolejnej estymacji, aby czynnik ten zdekomponować. Wyniki tej estymacji prezentuje tabela 4.

Tabela 4. Estymacja panelowa REM (zmienna zależna SAM)

\begin{tabular}{|lccccc}
\hline Współczynnik bład standardowy & $t$-Studenta & wartość p \\
Const & $-0,00904275$ & 0,00363545 & $-2,487$ & 0,0141 \\
WYN & $1,63268 e-05$ & $9,83302 e-07$ & 16,60 & $1,04 e-034$ \\
BEN & 0,000918447 & 0,000778445 & 1,180 & 0,2401 \\
DRO & $-0,000139840$ & $2,70953 e-05$ & $-5,161$ & $8,38 e-07$ \\
OFI & $-0,000148891$ & $3,90575 e-05$ & $-3,812$ & $0,0002 \quad * * *$ \\
M & $-1,94012 e-09$ & $2,08402 e-09$ & $-0,9309$ & 0,3535
\end{tabular}

Średn.aryt.zm.zależnej 0,022121 Odch.stand.zm.zależnej 0,008864

Suma kwadratów reszt 0,001353 Bład standardowy reszt 0,003120 
W modelu REM dwa z parametrów są nieistotne. Model ten nie posiada oszacowanego $\mathrm{R}^{2}$, natomiast współczynnik ten jest ważną, ale nie jedyną charakterystyką wartości równania. Dlatego też można zwrócić uwagę na błąd standardowy reszt $^{7}$. Jest on jednak najwyższy ze wszystkich trzech analizowanych modeli. Aby mieć pewność, który z modeli najlepiej opisuje badane zjawisko zastosowano kolejne dwa testy: test Breucha- Pagana i test Hausmana (tabela 5).

Tabela 5. Testy Breuscha- Pagana i Hausmana

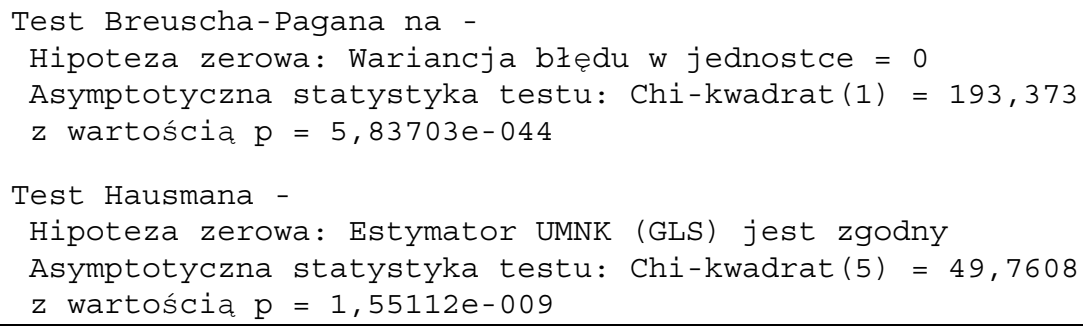

Na podstawie testu Breuscha-Pagana $=193,373$ przy empirycznym poziomie prawdopodobieństwa bliskim zeru dla tego testu można odrzucić H0 i stwierdzić, że model REM jest lepszy niż model podstawowy. Test Hausmana ostatecznie weryfikuje, który z trzech modeli najlepiej opisuje badane zjawisko. Na podstawie wartość testu $(49,7608)$ i wartości probvalue bliskiej zero można stwierdzić, że najlepszym i najefektywniejszym modelem jest model FEM (z dekompozycją wyrazu wolnego).

\section{Interpretacja wyników}

$\mathrm{Z}$ modelu z dekompozycją wyrazu wolnego usunięto zmienną nieistotną BEN. Otrzymano następujące wyniki.

Tabela 6. Estymacja FEM - z wyłączeniem zm. BEN (zm. zależna SAM)

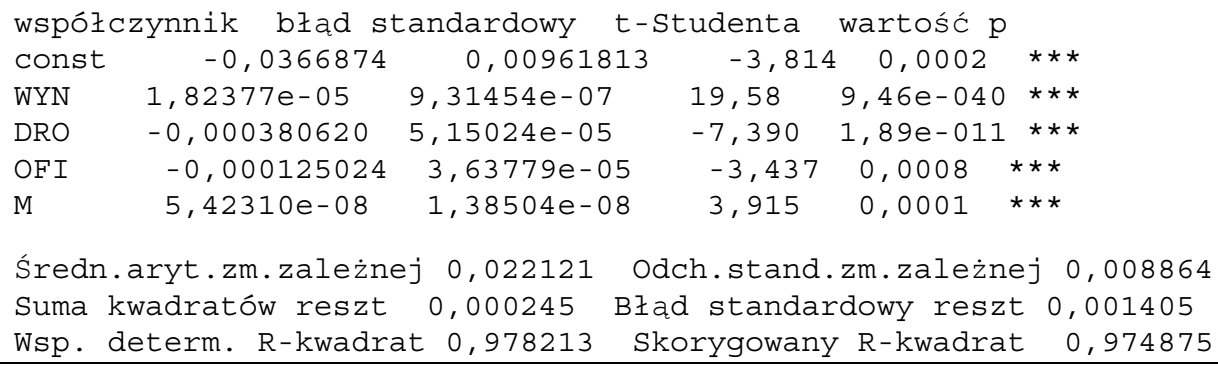

${ }^{7}$ J. Gajda, Ekonometria. Wykład i łatwe obliczenia w programie komputerowym, C.H. Beck, Warszawa 2004, s. 50-51. 
Na podstawie $\mathrm{R}^{2}$ można stwierdzić, że model opisuje badane zjawisko aż w 97\%.Największą istotność wykazuje zmienna WYN i mówi o tym, że gdy w kolejnym roku przeciętne wynagrodzenie wzrośnie o 100 zł to popyt na samochody osobowe o dużej pojemności silnika wrośnie o prawie 2 auta na tysiąc osób przy założeniu ceteris paribus. Jeżeli nasycenie dróg bitych zwiększy się o $100 \mathrm{~km}$ na $100 \mathrm{~km}^{2}$ to popyt spadnie o 38 aut na 100 tys. osób przy założeniu stałości innych czynników. Natomiast, gdy wzrośnie liczba ofiar śmiertelnych w wypadkach drogowych o 100 osób to popyt na samochody o dużej pojemności silnika spadnie o 38 aut na tysiąc osób przy założeniu ceteris paribus. Jeżeli w danym województwie wrośnie liczba mężczyzn w wieku produkcyjnych o 100 tys. to popyt również wrośnie o 5 aut na tysiąc osób przy założeniu innych stałości pozostałych czynników.

Wprowadzenie dekompozycji wyrazu wolnego było uzasadnione (każde z województw ma swój istotny wyraz wolny). Dekompozycję wyrazu wolnego dla wszystkich województw prezentuje tabela 7 .

Tabela 7. Dekompozycja wyrazu wolnego

\begin{tabular}{|lccc|}
\hline GroupCoefficient & Standard Error & \multicolumn{2}{c|}{ tratio } \\
łódzkie & -.03618 & .01036 & -3.49137 \\
mazowieckie & -.09485 & .02129 & -4.45459 \\
małopolskie & -.03586 & .01357 & -2.64374 \\
ślaskie & -.06054 & .02003 & -3.02210 \\
lubelskie & -.03267 & .00858 & -3.80933 \\
podkarpackie & -.03465 & .00838 & -4.13397 \\
podlaskie & -.02279 & .00470 & -4.84319 \\
świętokrzyskie & -.01440 & .00554 & -2.59723 \\
lubuskie & -.01386 & .00420 & -3.30255 \\
wielkopolskie & -.05270 & .01411 & -3.73437 \\
zachodniopomorskie & -.02967 & .00688 & -4.31558 \\
dolnoślaskie & -.04517 & .01197 & -3.77423 \\
opolskie & -.01315 & .00462 & -2.84865 \\
kujawsko-pomorskie & -.03360 & .00833 & -4.03600 \\
pomorskie & -.04050 & .00881 & -4.59733 \\
warmińsko-mazurskie & -.02641 & .00580 & -4.55027 \\
\hline
\end{tabular}

Bezwzględna wartość wyrazu wolnego dla województwa mazowieckiego jest najwyższa spośród wszystkich województw. Na tej podstawie można stwierdzić, że województwo to najsilniej wpływa na analizowany popyt. Najmniejszy wpływ wykazuje województwo opolskie. 


\section{Podsumowanie}

Analiza popytu na samochody osobowe o dużej pojemności silnika jest zagadnieniem bardzo złożonym. Problem w oszacowaniu przeciętnej ceny oraz losowość wielu czynników sprawia, że ciężko jednoznacznie oszacować równanie $\mathrm{w}$ pełni odzwierciedlające ten popyt. Mechanizm zaprezentowany w niniejszym artykule nie w pełni, ale obszernie opisuje badane zjawisko, wskazując na relacje zachodzące pomiędzy zmiennymi wykorzystanymi w równaniu.

W przeprowadzonym badaniu potwierdziła się hipoteza o silnym wpływie wynagrodzeń społeczeństwa na analizowany popyt. Jest to oczywiście zgodne z sensem ekonomicznym. Nie potwierdziła się natomiast hipoteza o wpływie ceny użytkowania (zmienna BEN). Parametr przy tej zmiennej był statystycznie nieistotny. Można przypuszczać, że osoby, które stać na droższy samochód nie będą zwracały aż tak dużej uwagi przed zakupem na koszty eksploatacyjne. Ponadto cena benzyny jest bardzo nieprzewidywalna i trudna do oszacowania, gdyż uwarunkowana jest od wielu czynników zewnętrznych. Być może przy podobnym badania należałoby uwzględnić zmienną odzwierciedlającą inne koszty użytkowania, gdyż cena benzyny jedynie odzwierciedla te koszty, a nie określa je w całości. Ten aspekt wymaga dalszych badań.

Nie potwierdziła się również hipoteza o ilości i stanie dróg o twardej nawierzchni. Wbrew początkowym założeniom wzrost zmiennej DRO powoduje spadek zmiennej SAM. Wyjaśnienia można doszukiwać się w stwierdzeniu, że zapotrzebowanie na samochody rośnie szybciej niż budowa dróg. Ta hipoteza podobnie jak poprzednia wymaga dalszych badań.

Ostatnie dwie hipotezy potwierdziły się z początkowymi założeniami. Im mniejsze bezpieczeństwo użytkowania tym popyt będzie spadał, gdyż jest to przestroga dla potencjalnych nowych kierowców. Mężczyźni wykazują skłonność do zakupu tego typu aut, dlatego wraz ze wzrostem liczby mężczyzn w wieku produkcyjnym $\mathrm{w}$ danym województwie rośnie popyt na samochody osobowe o dużej pojemności silnika.

\section{Literatura}

Dańska-Borsiak B., Przestrzenno-czasowe modelowanie zmian $w$ działalności produkcyjnej w Polsce, zastosowanie modeli panelowych, t. 1, [w:] B. Suchecki (red.), Dane panelowe i modele wielowymiarowe w badaniach ekonomicznych, Absolwent, Łódź 2000.

Gajda J., Ekonometria. Wyktad $i$ latwe obliczenia w programie komputerowym, C.H. Beck, Warszawa 2004.

Kufel T., Ekonometria. Rozwiazywanie problemów z wykorzystaniem programu GRETL, Wyd. Nauk. PWN, Warszawa 2007. 
Maciejewski G., Ryzyko w decyzjach nabywczych konsumentów, Wyd. UE w Katowicach, Katowice 2012.

Milewski R., Kwiatkowski E. (red.), Podstawy ekonomii, Wyd. Nauk. PWN, Warszawa 2007. Topolska J., Podstępny rynek. Zapiski podejrzliwego konsumenta, bis, Warszawa 2000. http://www.stat.gov.pl/bdl/app/strona.html?p_name=indeks (dostęp 30.11.2012).

\section{Streszczenie}

Artykuł prezentuje przestrzenno-czasową analizę popytu na samochody osobowe o dużej pojemności silnika w polskich województwach w latach 2003-2011. Do szacowania popytu zastosowano niekonwencjonalne podejście pomijające cenę analizowanego dobra. Narzędziami wykorzystanymi do zbudowania równania regresji były modele panelowe: wykorzystujące metodę najmniejszych kwadratów, z dekompozycją wyrazu wolnego oraz z dekompozycją składnika losowego. Otrzymane wyniki estymacji pozwoliły na wskazanie zależności oraz siły wpływu poszczególnych czynników na kształtowanie analizowanego popytu.

\section{Summary}

\section{DEMAND FOR PASSENGER CARS WITH HIGH ENGINE CAPACITY IN POLAND - SPATIAL AND TEMPORAL ANALYSIS}

The article presents the spatial and temporal analysis of demand for passenger cars with high engine capacity in the Polish provinces in the years 2003-2011. The estimation of demand used unconventional approach which skip the price of the analyzed good. To build balance regression were used panel models which use method of least squares with decomposition of intercept and decomposition of random component. The estimation results allowed to show dependency and impact of particular factors on analyzed demand. 